J Am Chem Soc. 2000 November 8; 122(44): 11027-11028. doi:10.1021/ja0027416.

\title{
Total Synthesis of (-)-Laulimalide
}

\author{
Arun K. Ghosh and Yong Wang \\ Department of Chemistry, University of Illinois at Chicago, 845 West Taylor Street, Chicago, \\ Illinois 60607
}

Laulimalide (1), also known as figianolide B, a 20-membered macrolide isolated from the Indonesian sponge Hyattella sp., has shown remarkable antitumor activities. ${ }^{1}$ Recently, Laulimalide was also isolated from an Okinawan sponge Fasciospongia rimosa. ${ }^{2}$ It displayed potent cytotoxicity against the $\mathrm{KB}$ cell line with an $\mathrm{IC}_{50}$ value of $15 \mathrm{ng} / \mathrm{mL} .{ }^{1}$ Furthermore, it has shown cytotoxicity against P388, A549, HT29, and MEL28 cell lines in the range of 10$50 \mathrm{ng} / \mathrm{mL}$ (IC 50 values). ${ }^{2 \mathrm{~b}}$ The structure of $\mathbf{1}$ was initially established by NMR studies. Subsequently, its absolute configuration was established by X-ray analysis by Higa and coworkers. ${ }^{2}$ The significant clinical potential of laulimalide has stimulated considerable interest in its synthesis and structure-function studies. ${ }^{3}$ Herein, we report the first synthesis of (-)-laulimalide $\mathbf{1}$.

As outlined in Figure 1, our synthetic strategy of laulimalide is convergent and involves the assembly of $\mathrm{C}_{3}-\mathrm{C}_{16}$ segment $\mathbf{2}$ and $\mathrm{C}_{17}-\mathrm{C}_{28}$ segment $\mathbf{3}$ by Julia olefination, followed by an intramolecular Horner-Emmons reaction between the $\mathrm{C}_{19}$ phosphonoacetate and $\mathrm{C}_{3}$ aldehyde. The sensitive epoxide at $\mathrm{C}_{16}-\mathrm{C}_{17}$ was selectively introduced at the final stage of the synthesis by Sharpless epoxidation. ${ }^{4}$ The construction of both dihydropyran rings of laulimalide was achieved by ring-closing olefin metathesis utilizing Grubbs' catalyst as the key step. ${ }^{5}$

The synthesis of $\mathrm{C}_{3}-\mathrm{C}_{16}$ segment is accomplished by modifications of the previously published sequence. ${ }^{3 a}$ As outlined in Scheme 1 , diastereomerically pure $\delta$-lactone $\mathbf{5}$ was prepared efficiently by exposure of acryloyl ester 4 to Grubbs' catalyst (10 mol \%) in $\mathrm{CH}_{2} \mathrm{Cl}_{2} \cdot{ }^{3 \mathrm{a}}$ DIBAL reduction of 5 at $-78{ }^{\circ} \mathrm{C}$ in $\mathrm{CH}_{2} \mathrm{Cl}_{2}$ followed by reaction with ethanol and CSA afforded the ethyl glycoside. ${ }^{6}$ Reaction of this ethyl acetal with tertbutyldimethylsilyl vinyl ether and Montmorillonite K-10 as the Lewis acid in $\mathrm{CH}_{2} \mathrm{Cl}_{2}$ at $23{ }^{\circ} \mathrm{C}$ followed by $\mathrm{NaBH}_{4}$ reduction of the resulting aldehyde afforded the corresponding dihydropyran as a single isomer (by ${ }^{1} \mathrm{H}$ and ${ }^{13} \mathrm{C} \mathrm{NMR}$ ). Protection of the alcohol with $\mathrm{TBSCl}$ and imidazole furnished the TBS ether $\mathbf{6}$. Removal of the benzyl group by lithium in liquid ammonia provided the alcohol which was subsequently converted to iodide 7 . To install the $\mathrm{C}_{13}$ methylene unit and the $\mathrm{C}_{15}$ hydroxyl group, alkylation of lactone $\mathbf{8}$ was carried out by treatment with $\mathrm{NaH}$ in $\mathrm{DMF}$ at $0{ }^{\circ} \mathrm{C}$ for $15 \mathrm{~min}$ followed by reaction with iodide 7 at $23{ }^{\circ} \mathrm{C}$ for $15 \mathrm{~min}$ and then $60^{\circ} \mathrm{C}$ for $12 \mathrm{~h}$, which furnished lactone 9 as a mixture

Supporting Information Available:

Experimental procedures and spectral data for compounds 1-3, 6-11, 15-20; ${ }^{1} \mathrm{H}$ NMR spectra for compounds 1, 3, 11, 15-17, 19, 20; and ${ }^{13} \mathrm{C}$ NMR for compounds $\mathbf{1}, \mathbf{3}, \mathbf{1 1}, \mathbf{1 7}$, and $\mathbf{1 9}(\mathrm{PDF})$. This material is available free of charge via the Internet at http:// pubs.acs.org. 
(4.2:1 by ${ }^{1} \mathrm{H}$ NMR) of isomers. Reduction of the mixture of lactone 9 by Red-Al provided the diol 10. Benzoylation of $\mathbf{1 0}$ afforded the corresponding dibenzoate which was exposed to $\mathrm{Na}-\mathrm{Hg}$ in $\mathrm{MeOH}$ at $-20{ }^{\circ} \mathrm{C}$ to provide the olefin 11. ${ }^{7}$ Protection of the $\mathrm{C}_{15}$ hydroxyl group as a MOM ether, removal of the PMB group and Swern oxidation of the resulting alcohol furnished the $\mathrm{C}_{3}-\mathrm{C}_{16}$ segment, aldehyde 2 .

The synthesis of the $\mathrm{C}_{17}-\mathrm{C}_{28}$ segment $\mathbf{3}$ has been achieved by modification of reaction sequences published previously. ${ }^{3 \mathrm{~b}}$ Optically active dihydropyran derivative 12 was prepared in multigram quantity by utilizing ring-closing olefin methathesis ${ }^{5}$ and Corey-Fuchs' homologation ${ }^{8}$ reactions as the key steps. The alkynyl anion of $\mathbf{1 2}$ was readily obtained by treatment with $n$ - BuLi at $-78{ }^{\circ} \mathrm{C}$ for $1 \mathrm{~h}$ followed by warming to $23{ }^{\circ} \mathrm{C}$ for $1 \mathrm{~h}$ (Scheme 2). Reaction of the resulting alkynyl anion with optically active aldehyde 13 at $-78{ }^{\circ} \mathrm{C}$ furnished a diastereomeric mixture (1.8: 1) of alcohols 14 and 15, which upon oxidation with DessMartin periodinane ${ }^{9}$ gave the corresponding alkynyl ketone. L-Selectride reduction of this ketone at $-78{ }^{\circ} \mathrm{C}$ furnished the desired synalkynyl alcohol 15 as a single diastereomer (by ${ }^{1} \mathrm{H}$ NMR and ${ }^{13} \mathrm{C}$ NMR). Red-Al reduction of $\mathbf{1 5}$ set the $\mathrm{C}_{21}-\mathrm{C}_{22}$ trans-olefin geometry. Removal of the $\mathrm{C}_{19}$ PMB group by exposure to TFA ${ }^{10}$ and subsequent reaction of the resulting diol with $p$-methoxybenzylidene acetal and CSA provided acetal 16. DIBAL reduction of 16 at $-78{ }^{\circ} \mathrm{C}$ in $\mathrm{CH}_{2} \mathrm{Cl}_{2}$ afforded the $\mathrm{C}_{17}-\mathrm{C}_{28}$ segment 3 as a single regio isomer (by ${ }^{1} \mathrm{H}$ and ${ }^{13} \mathrm{C}$ NMR).

Our subsequent synthetic strategy calls for the assembly of fragments $\mathbf{2}$ and $\mathbf{3}$ by Julia olefination (Scheme 3). Thus, lithiation of sulfone derivative $\mathbf{3}$ with 2.1 equiv of $n$-BuLi in THF at $-78{ }^{\circ} \mathrm{C}$ for $15 \mathrm{~min}$ followed by reaction of the resulting dianion with the aldehyde 2 at $-78{ }^{\circ} \mathrm{C}$ to $-40{ }^{\circ} \mathrm{C}$ for $2 \mathrm{~h}$ furnished the expected R-hydroxy sulfone derivatives. The hydroxy sulfone was transformed into the corresponding $\mathrm{C}_{16}-\mathrm{C}_{17}$ olefin in a two step sequence involving (1) acylation of the hydroxy sulfone derivatives with $\mathrm{Ac}_{2} \mathrm{O}, \mathrm{Et}_{3} \mathrm{~N}$ and DMAP (cat.) and (2) exposure of the resulting acetates to $\mathrm{Na}(\mathrm{Hg})$ in methanol at $-20{ }^{\circ} \mathrm{C}$ for $2 \mathrm{~h}$ followed by warming the reaction to $23^{\circ} \mathrm{C}$ for $30 \mathrm{~min}$. The $\mathrm{C}_{16}-\mathrm{C}_{17}$ trans olefin 17 was obtained in $34 \%$ yield along with $10 \%$ cis-olefin, which was readily separated by silica gel chromatography.

Subsequent elaboration to the macrolactone possessing $\mathrm{C}_{2}-\mathrm{C}_{3}$ cis-olefin geometry proved to be a formidable task. We finally relied upon an intramolecular Horner-Emmons reaction of $\mathrm{C}_{19}$ phosphonoacetate and $\mathrm{C}_{3}$ aldehyde using Still's protocol. ${ }^{11}$ Thus, acylation of $\mathrm{C}_{19}$ hydroxyl group with bis-(2,2,2-trifluoroethyl)-phosphonoacetic acid followed by removal of the TBS group by exposure to aqueous acetic acid in THF at $23{ }^{\circ} \mathrm{C}$ furnished the acetate derivative 18 in near quantitative yield. ${ }^{12}$ Oxidation of 18 with Dess-Martin periodinane provided the $\mathrm{C}_{3}$ aldehyde which upon treatment with $\mathrm{K}_{2} \mathrm{CO}_{3}$ in the presence of 18-C-6 at $-20{ }^{\circ} \mathrm{C}$ for $30 \mathrm{~min}$ and then at $0{ }^{\circ} \mathrm{C}$ for $2.5 \mathrm{~h}$ furnished a mixture (2:1) of macrolactones 19 and 20 in $84 \%$ yield (Scheme 3). Both cisand trans-lactones were separated by silica gel chromatography. Horner-Emmons reaction of the corresponding (diphenylphosphono)acetate derivative provided slight improvement of the cis-selectivity (cis:trans $=1: 1.7,69 \%$ isolated yield). ${ }^{13}$ Further attempts to improve the ratio for $\mathbf{2 0}$ by changing reaction conditions or $\mathrm{C}_{20}$ protecting group have been unsuccessful. The overall 
yield of the desired cis-macrolactone 20 was however improved to $47 \%$ after photoisomerization of the trans-macro-lactone 19. ${ }^{14}$ Thus, irradiation of $\mathbf{1 9}$ in ether under UV in a Rayonet photochemical reactor for $50 \mathrm{~min}$ afforded a mixture of trans-lactone 19 (33\%) and the cis-lactone 20 (33\%) which were separated by chromatography. The identity of the cis-olefin geometry of $\mathbf{2 0}$ was established by its observed coupling constant $(J=11.6$ $\mathrm{Hz}$ ). Macrolactone $\mathbf{2 0}$ was converted to synthetic (-)-laulimalide $\mathbf{1}$ as follows: removal of the MOM group by refluxing with PPTS in $t-\mathrm{BuOH},{ }^{15}$ exposure of the resulting alcohol to Sharpless epoxidation ${ }^{4}$ with (+)-DET and removal of the $\mathrm{C}_{20}$ PMB ether by exposure to DDQ. Spectral data $\left({ }^{1} \mathrm{H}\right.$ and $\left.{ }^{13} \mathrm{C} \mathrm{NMR}\right)$ of synthetic $1\left([a]^{23} \mathrm{D}-196 c 0.23, \mathrm{CHCl}_{3}\right)$ are identical to that from a sample of natural laulimalide (lit. ${ }^{2 \mathrm{a}}[\mathrm{a}]^{29} \mathrm{D}-200 c 1.03, \mathrm{CHCl}_{3}$ ) kindly provided by Professor Higa.

Thus, a stereocontrolled synthesis of (-)-laulimalide has been achieved. Considering its clinical potential as an antitumor agent, the present synthesis will enable important structure -function studies as well as synthesis of structural variants of laulimalide. Further improvement in synthesis and biological studies are currently in progress.

\section{Supplementary Material}

Refer to Web version on PubMed Central for supplementary material.

\section{Acknowledgment.}

Financial support by the National Institutes of Health (GM 55600) is gratefully acknowledged. We also thank Professor Higa for providing a sample of natural laulimalide and Professor Forsyth for the experimental details of bis-(2,2,2-trifluoroethyl)phosphonoacetic acid.

\section{References}

(1). (a)Quinoa E; Kakou Y; Crews P J. Org. Chem 1988, 53, 3642.(b)Corley DG; Herb R; Moore RE; Scheuer PJ; Paul VJ J. Org. Chem 1988, 53, 3644.

(2). (a)Jefford CW; Bernardinelli G; Tanaka J-I; Higa T Tetrahedron Lett 1996, 37, 159.(b)Tanaka J-I; Higa T; Bernardinelli G; Jefford CW Chem. Lett 1996, 255.

(3). (a)Ghosh AK; Wang Y Tetrahedron Lett 2000, 41, 2319.(b)Ghosh AK; Wang Y Tetrahedron Lett 2000, 41, 4705.(c)Mulzer J; Hanbauer M Tetrahedron Lett 2000, 41, 33.(d)Shimizu A; Nishiyama S Synlett 1998, 1209.(e)Ghosh AK; Mathivanan P; Cappiello J Tetrahedron Lett 1997, 38, 2427. [PubMed: 30344352]

(4). Johnson RA; Sharpless KB In Catalytic Asymmetric Synthesis; Ojima I; Ed.; VCH Publishers: New York, 1993, p 103-158.

(5). Grubbs RH; Chang S Tetrahedron 1998, 54, 4413 and references therein.

(6). For a related method, see: Dahanukar VH; Rychnovsky SD J. Org. Chem 1996, 61, 8317. [PubMed: 11667826]

(7). Lee GH; Lee HK; Choi EB; Kim BT; Pak CS Tetrahedron Lett 1995, 36, 5607.

(8). Corey EJ; Fuchs PL Tetrahedron Lett 1972, 3769.

(9). Meger SD; Schreiber SL J. Org. Chem 1994, 59, 7549.

(10). Yan L; Kahne D Synlett 1995, 523.

(11). Still WC; Gennari C Tetrahedron Lett 1983, 24, 4405.

(12). This protocol was recently employed in the synthesis of phorboxazole A. See: Forsyth CJ; Ajmed F; Cink RD; Lee CS J. Am. Chem. Soc 1998, 120, 5597.

(13). Ando KJ Org. Chem 1999, 64, 8406 and references therein. 
(14). Smith AB; Lupo AT; Ohba M; Chen KJ Am. Chem. Soc 1989, 111, 6648 and references therein. (15). Monti H; Leandri G; Klos-Ringquet M; Corriol C Synth. Commun 1983, 13, 1021. 

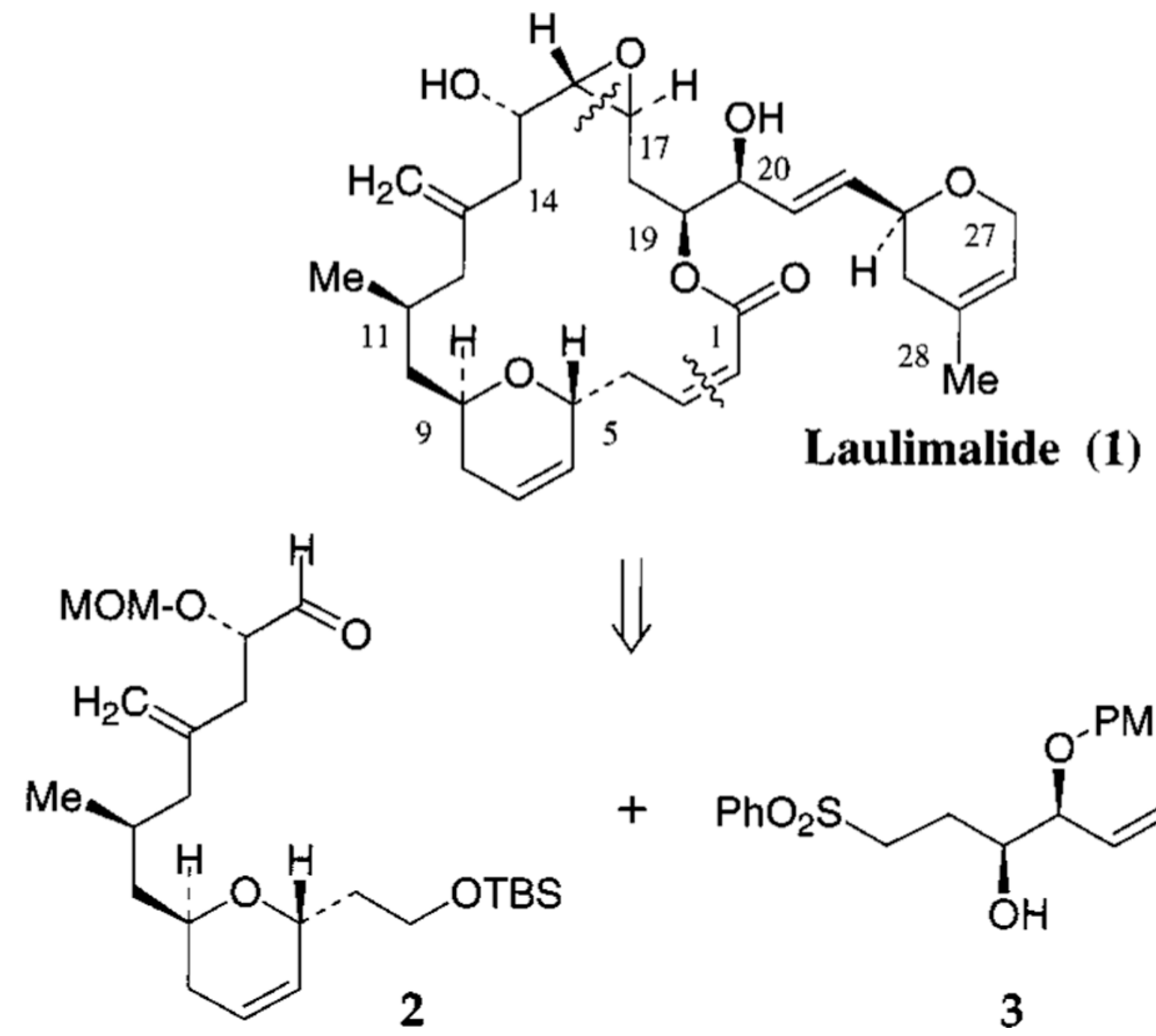

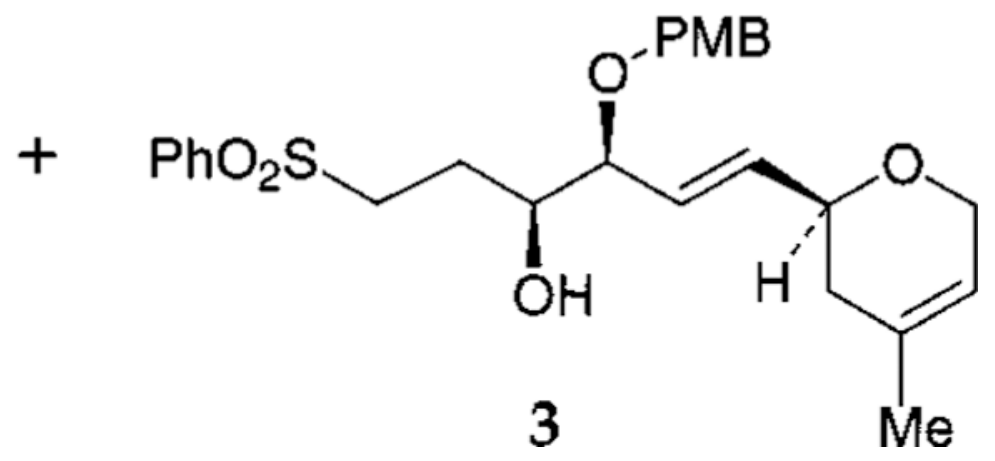

Figure 1. 


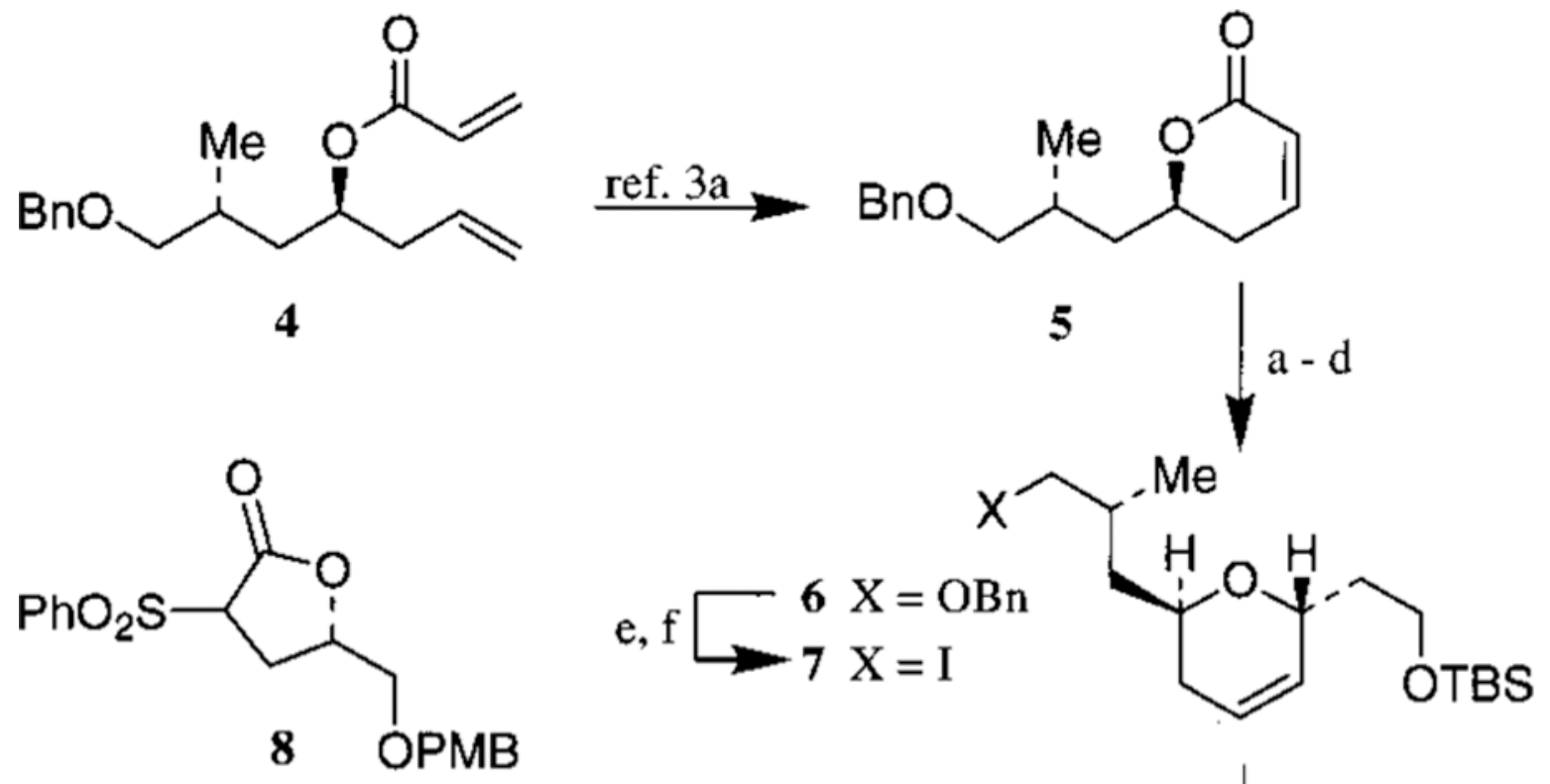

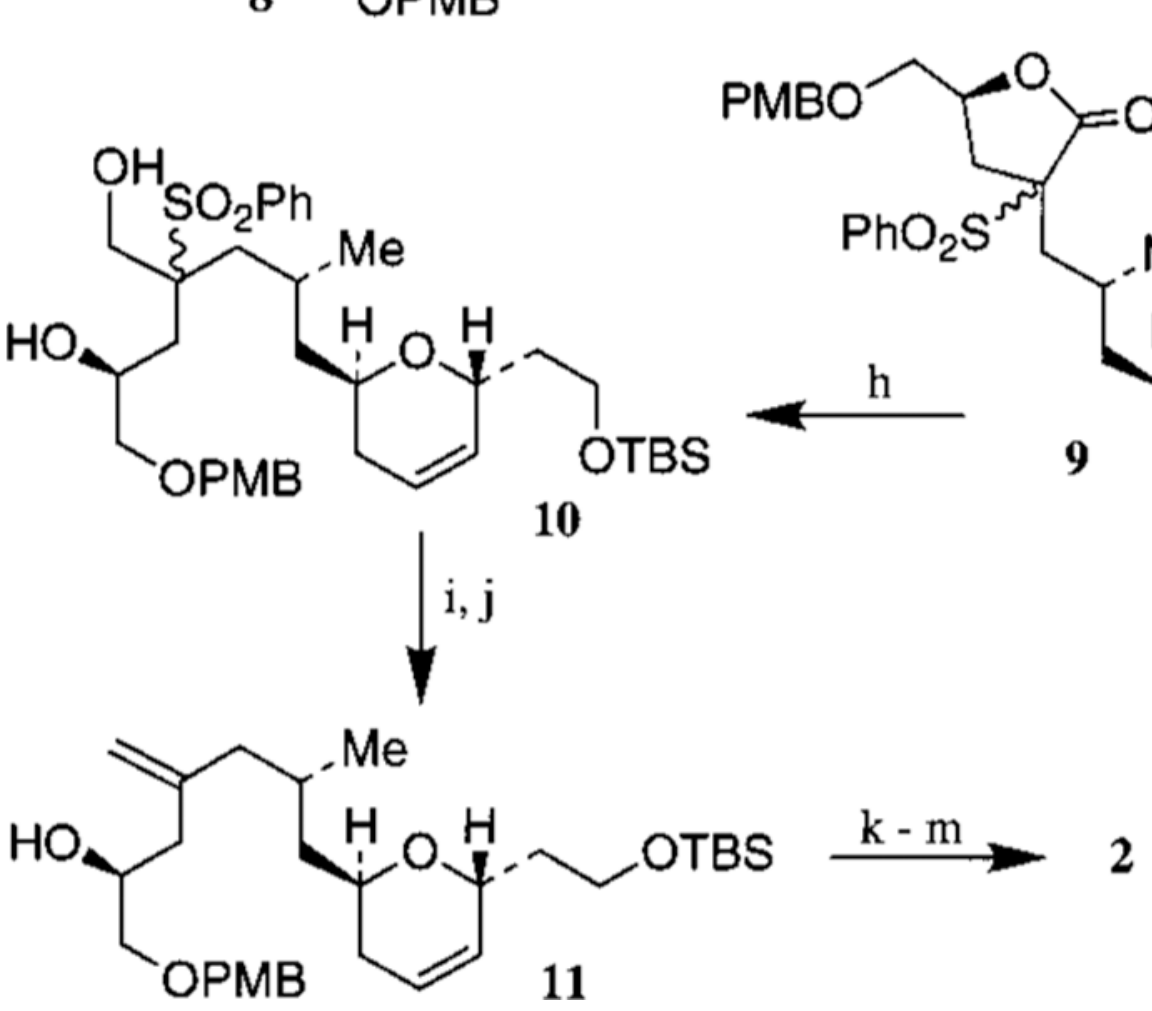

Scheme $1^{\mathrm{a}}$

${ }^{a}$ (a) Dibal-H, $-78{ }^{\circ} \mathrm{C}$ then CSA, EtOH, $23{ }^{\circ} \mathrm{C}$; (b) K-10, $\mathrm{CH}_{2}=\mathrm{CHOTBS}, 23^{\circ} \mathrm{C}$; (c)

$\mathrm{NaBH}_{4}, \mathrm{MeOH}, 0^{\circ} \mathrm{C}$ (54\%); (d) TBSCl, imidazole, DMF, $23{ }^{\circ} \mathrm{C}$ (75\%); (e) Li, $\mathrm{NH}_{3}$ (95\%);

(f) $\mathrm{I}_{2}, \mathrm{PPh}_{3}$, Imidazole (96\%); (g) 8, NaH, DMF, $0^{\circ} \mathrm{C}$ then iodide 7, $60{ }^{\circ} \mathrm{C}(89 \%)$; (h) Red-

$\mathrm{Al}$, THF, $0{ }^{\circ} \mathrm{C}$; (i) $\mathrm{PhCOCl}, \mathrm{Et}_{3} \mathrm{~N}$, DMAP (cat.); (j) $\mathrm{Na}\left(\mathrm{Hg}\right.$ ), $\mathrm{Na}_{2} \mathrm{HPO}_{4}, \mathrm{MeOH},-20^{\circ}$ to $23{ }^{\circ} \mathrm{C}$ (72\%); (k) MOMCl, $i-\mathrm{Pr}_{2} \mathrm{NEt}, 23{ }^{\circ} \mathrm{C}$; (l) DDQ, pH 7 buffer, $23^{\circ} \mathrm{C}(81 \%)$; (m) DMSO, $(\mathrm{COCl})_{2}, i-\mathrm{Pr}_{2} \mathrm{NEt},-60^{\circ} \mathrm{C}(85 \%)$. 

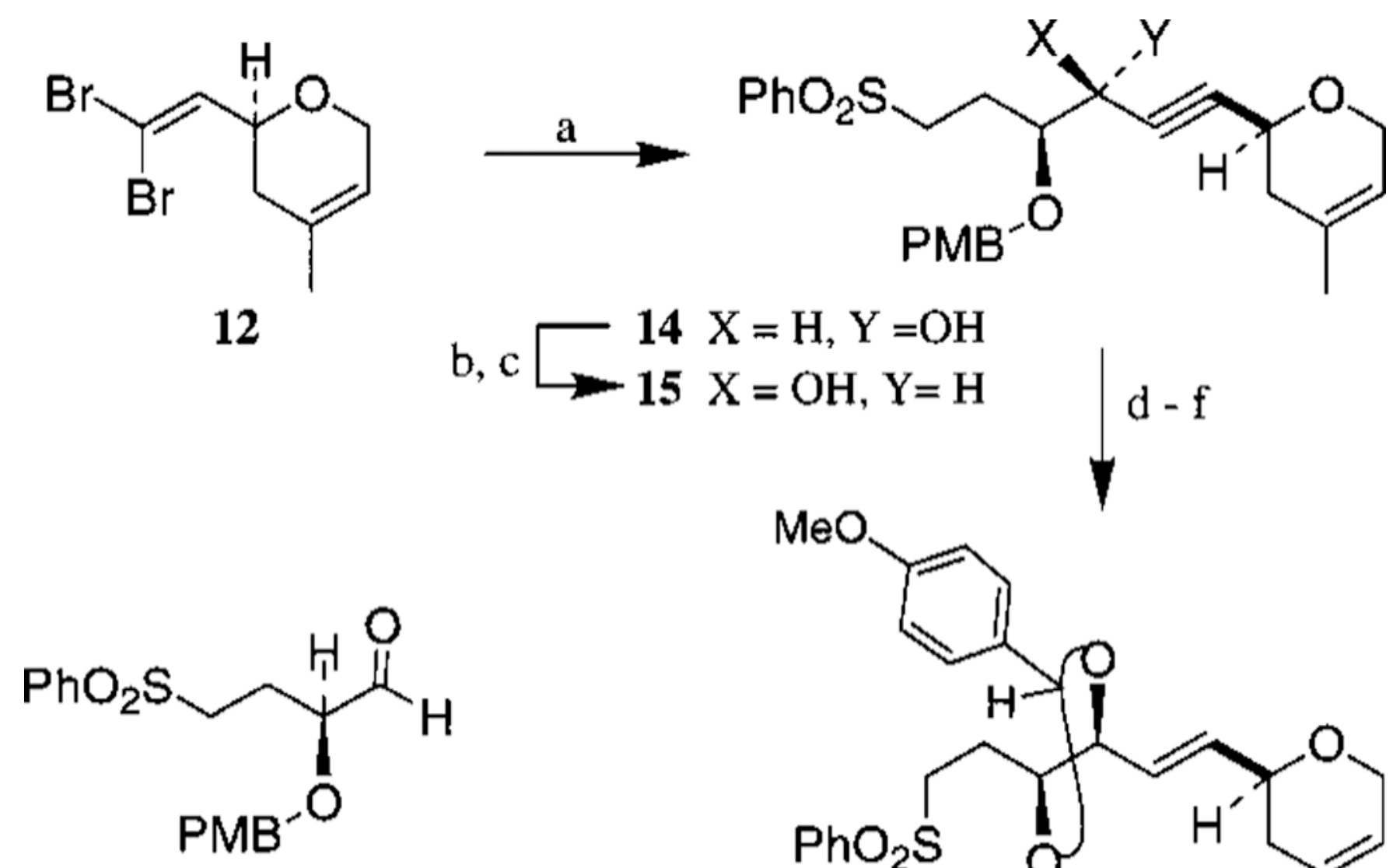

$\begin{aligned} & \mathrm{b}, \mathrm{c} \square \\ & 14 \mathrm{X}=\mathrm{H}, \mathrm{Y}=\mathrm{OH} \\ & 15 \mathrm{X}=\mathrm{OH}, \mathrm{Y}=\mathrm{H}\end{aligned} \mid \mathrm{d}-\mathrm{f}$

13

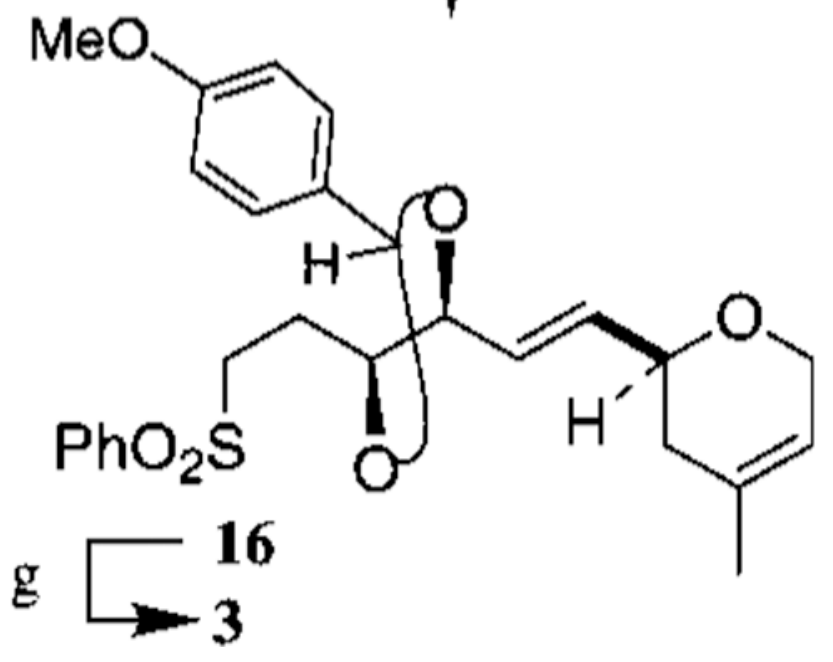

Scheme $2^{\mathbf{a}}$

${ }^{a}$ (a) $n$ - BuLi, $-78{ }^{\circ} \mathrm{C}, 1 \mathrm{~h}$ and $23{ }^{\circ} \mathrm{C}, 1 \mathrm{~h}$ then $13,-78{ }^{\circ} \mathrm{C}\left(64 \%\right.$ ); (b) Dess-Martin, $\mathrm{CH}_{2} \mathrm{Cl}_{2}$, $23{ }^{\circ} \mathrm{C}$ (81\%); (c) L-Selectride, THF, $-78{ }^{\circ} \mathrm{C}(87 \%)$; (d) Red-Al, THF, $-20{ }^{\circ} \mathrm{C}(81 \%)$; (e) $\mathrm{CF}_{3} \mathrm{CO}_{2} \mathrm{H}, \mathrm{CH}_{2} \mathrm{Cl}_{2}, 23{ }^{\circ} \mathrm{C}$; (f) $p$-MeO-Ph-CH(OMe $)_{2}, \mathrm{CSA}, \mathrm{CH}_{2} \mathrm{Cl}_{2}, 23{ }^{\circ} \mathrm{C}(71 \%)$; (g) Dibal-H, $\mathrm{CH}_{2} \mathrm{Cl}_{2},-78^{\circ} \mathrm{C}(74 \%)$. 


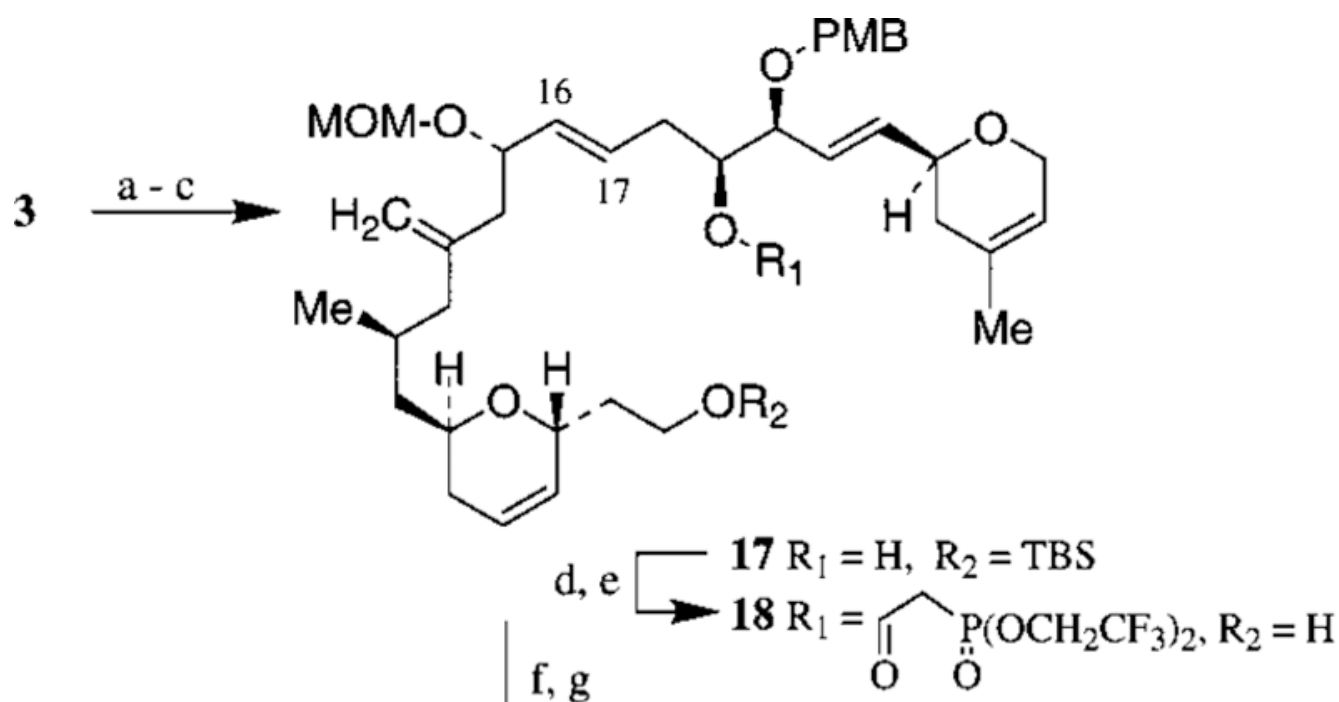

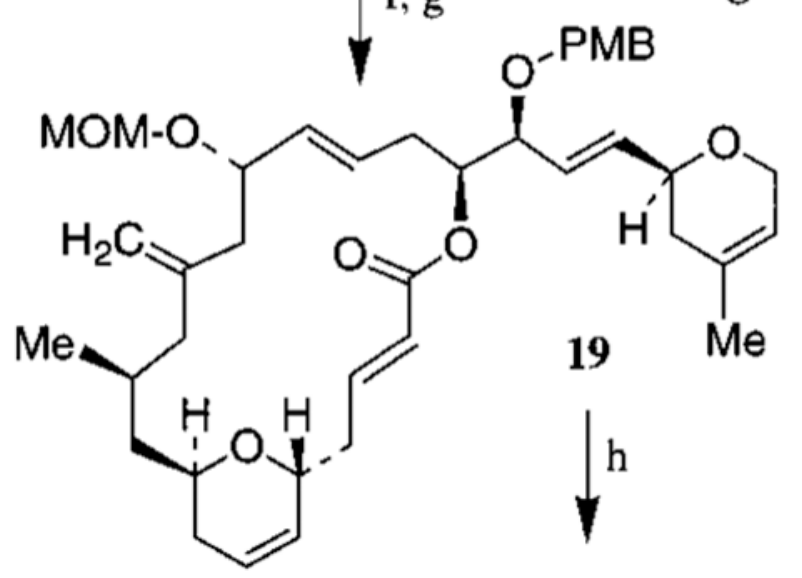

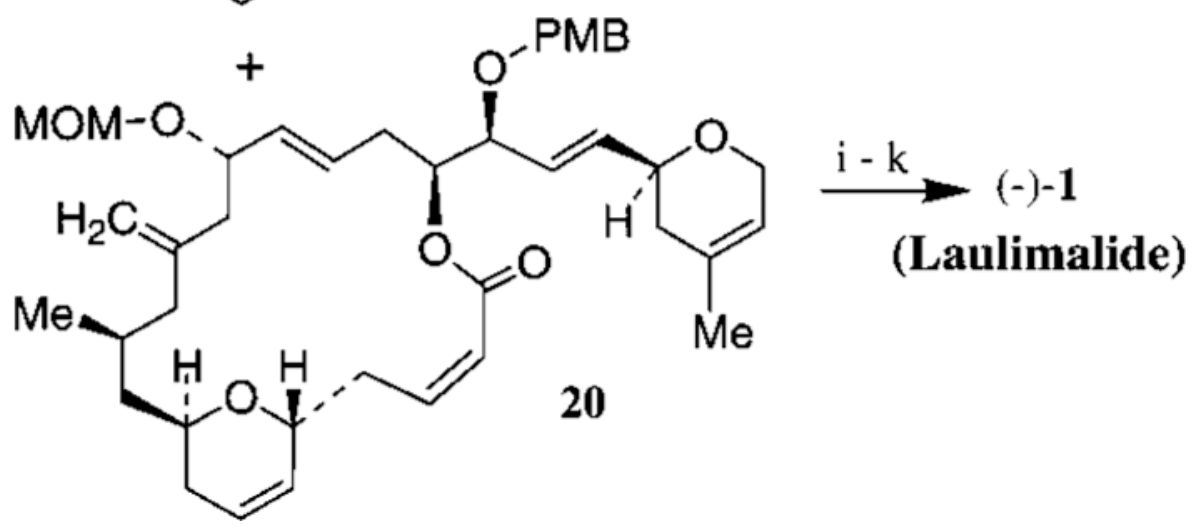

Scheme $3^{\mathbf{a}}$

a (a) $n$-BuLi, $-78^{\circ} \mathrm{C}, 15 \mathrm{~min}$, Then $2,-78$ to $-40{ }^{\circ} \mathrm{C}, 2 \mathrm{~h}$; (b) $\mathrm{Ac}_{2} \mathrm{O}, \mathrm{Et}_{3} \mathrm{~N}$, DMAP (cat.); (c) $\mathrm{Na}(\mathrm{Hg}), \mathrm{Na}_{2} \mathrm{HPO}_{4}, \mathrm{MeOH},-20$ to $23{ }^{\circ} \mathrm{C}(34 \%)$; (d) $\left(\mathrm{CF}_{3} \mathrm{CH}_{2} \mathrm{O}\right)_{2} \mathrm{P}(\mathrm{O}) \mathrm{CH}_{2} \mathrm{CO}_{2} \mathrm{H}$, $\mathrm{Cl}_{3} \mathrm{C}_{6} \mathrm{H}_{2} \mathrm{COCl}$, $i$-Pr 2 NEt, DMAP; (e) AcOH-THF- $\mathrm{H}_{2} \mathrm{O}$ (3:1:1), $23{ }^{\circ} \mathrm{C}$ (99\%); (f) Dess -Martin, $\mathrm{CH}_{2} \mathrm{Cl}_{2}, 23{ }^{\circ} \mathrm{C}(79 \%)$; (g) $\mathrm{K}_{2} \mathrm{CO}_{3}, 18-\mathrm{C}-6,-20$ to $0{ }^{\circ} \mathrm{C}(84 \%)$; (h) $h v, \mathrm{Et}_{2} \mathrm{O}, 50$ $\min (66 \%)$; (i) PPTS, $t$-BuOH, $84{ }^{\circ} \mathrm{C}(45 \%)(\mathrm{j}) \mathrm{Ti}\left(\mathrm{O}^{i} \mathrm{Pr}\right)_{4},(+)-\mathrm{DET}, t$-BuOOH, $-20{ }^{\circ} \mathrm{C}$; (k) DDQ, pH 7, $23{ }^{\circ} \mathrm{C}(48 \%)$. 